\title{
Advances in Microalgal Research in Brazil
}

\author{
Ângelo Paggi Matos ${ }^{1^{*}}$
}

https://orcid.org/0000-0002-6600-2290

${ }^{1}$ Federal University of Santa Catarina, Center of Agricultural Sciences, Florianópolis, Santa Catarina, Brazil.

Editor-in-Chief: Paulo Vitor Farago

Associate Editor: Paulo Vitor Farago

Received: 2020.08.19; Accepted: 2021.02.24.

*Correspondence: angelosotam@gmail.com; matos.a@posgrad.ufsc.br (A.P.M).

\section{HIGHLIGHTS}

- Microalgae science is a very active area of research in Brazil.

- Brazilian government has been funding projects in algal biotechnology.

- Brazilian institutes have gathered a deep knowledge in algal research.

- Researchers have been focused on bioproducts and biofuels from microalgae.

Abstract: Microalgae research has attracted interest worldwide and in order to advance algal biotechnology in Brazil, government has been funding several projects. In the last 10 years, two main funds were provided by the National Council of Scientific and Technological Development (CNPq) agency to researchers in Brazil, who study the potential uses of microalgae for biomass, bioproducts and biofuels production. These funded projects addressed aspects of algal strain identification, development of algal cultivation techniques, designing photobioreactors and raceway ponds, modeling harvesting and dewatering process, maximizing biomass and oil productivities, characterizing chemical composition with different extractions systems and determining physiochemical properties of biodiesel. This review presents the state of art of algal research conducted by Brazilian institutions. Special attention is given to the recent progress on microalgal cultivation, high-value products extracted from microalgae and potential biofuels production. This review may serve as a policy instrument for planning next steps for algal research in Brazil as well as for attracting attention from international researchers who work with microalgae and would like to pursue a future partnership on algal research with Brazilian research institutions.

Keywords: microalgae culturing; algal biotechnology; photobioreactor; bioprocess; bioproducts; biofuels.

\section{INTRODUCTION}

Microalgae are unicellular photosynthetic microorganisms typically found in freshwater and marine systems that convert sunlight, water and carbon dioxide to algal biomass. With an outstanding ability to synthesize several chemical compounds, their biomass is rich in compounds like proteins [1], carbohydrates and sugars [2], lipids and fatty acids [3], pigments [4], polymers [5], enzymes [6], peptides [7] and sterols [8]. The biodiversity of microalgae is enormous, representing an almost untapped resource for food manufacturing [9], fine chemical synthesis [10], biofertilizers [11] and biofuels production [12,13].

Cultivation of microalgae at large-scale have been conducted for over 50 years [14]. Chlorella cultivation was the first microalgae species produced at commercial interest in Japan in early 1960, [15]. In early 1970, 
the cyanobacteria Spirulina was mass scale cultivated in Mexico, South America [16]. Since 1980, the salttolerant microalgae Dunaliella salina has been cultivated in large scale in Australia and Israel for $\beta$-carotene production [17]. The main reason for the successful growth of these microalgae species is the particular ability to grow at high selective environments, i.e., Spirulina thrives well at high bicarbonate concentration (16.8 $\mathrm{g} \mathrm{L}^{-1}$ of $\left.\mathrm{NaHCO}_{3}\right)$ and elevated $\mathrm{pH}(10.0-11.0)$ [18], Dunaliella salina grows well at high salinity (10\% to $35 \%(\mathrm{w} / \mathrm{v}) \mathrm{NaCl}$ [19], while Chlorella has the capability to tolerate high source of nutrients, notably nitrogen and phosphorus (1:4 to $1: 40 \mathrm{~N}: \mathrm{P}$ ratio), usually found in agricultural wastewater, such as digested abattoir effluent [20].
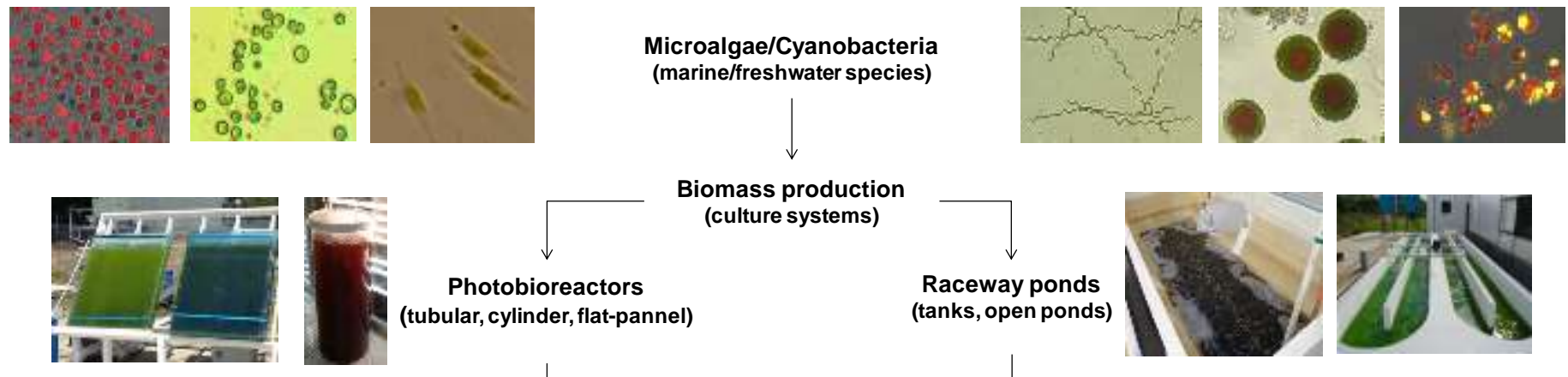

Biomass production (culture systems) Photobioreactors
(tubular, cylinder, flat-pannel)
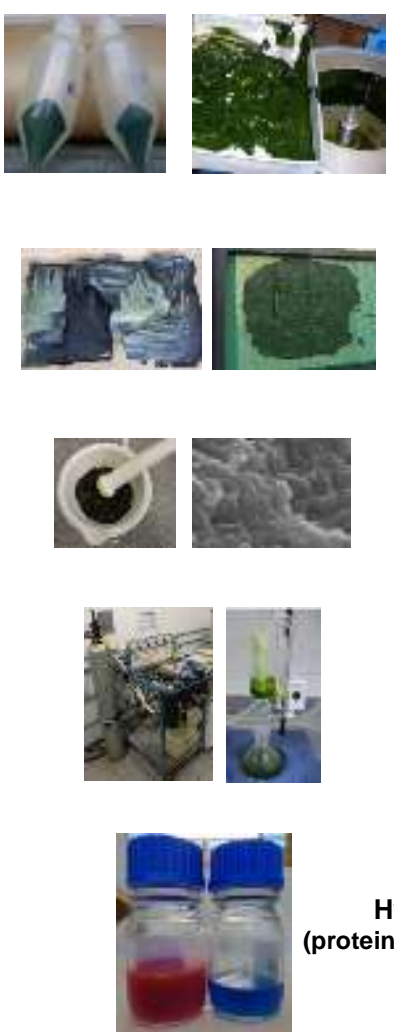

Hydrophilic compounds (proteins, carbohydrates, phycocyanin)
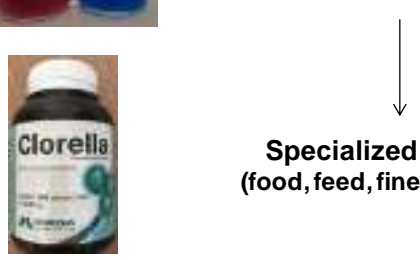

Specialized Industry (food, feed, fine chemicals)

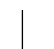
(centrifugation, flocculation, filtration)

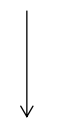

Drying

(natural drying, dehydrator)

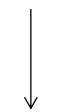

Cell disruption

(crunch, ultrasound, non-thermal plasma)

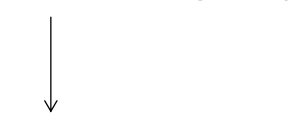

Extraction

(freeze-thaw, polar solvents, supercritical- $\mathrm{CO}_{2}$ )

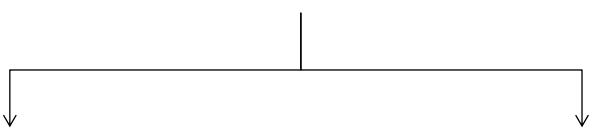

Hydrophobic compounds (lipids, isoprenes, carotenoids)

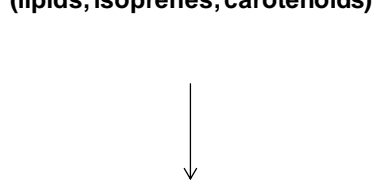

Further Fractionation (food, feed, chemicals, biofuels)
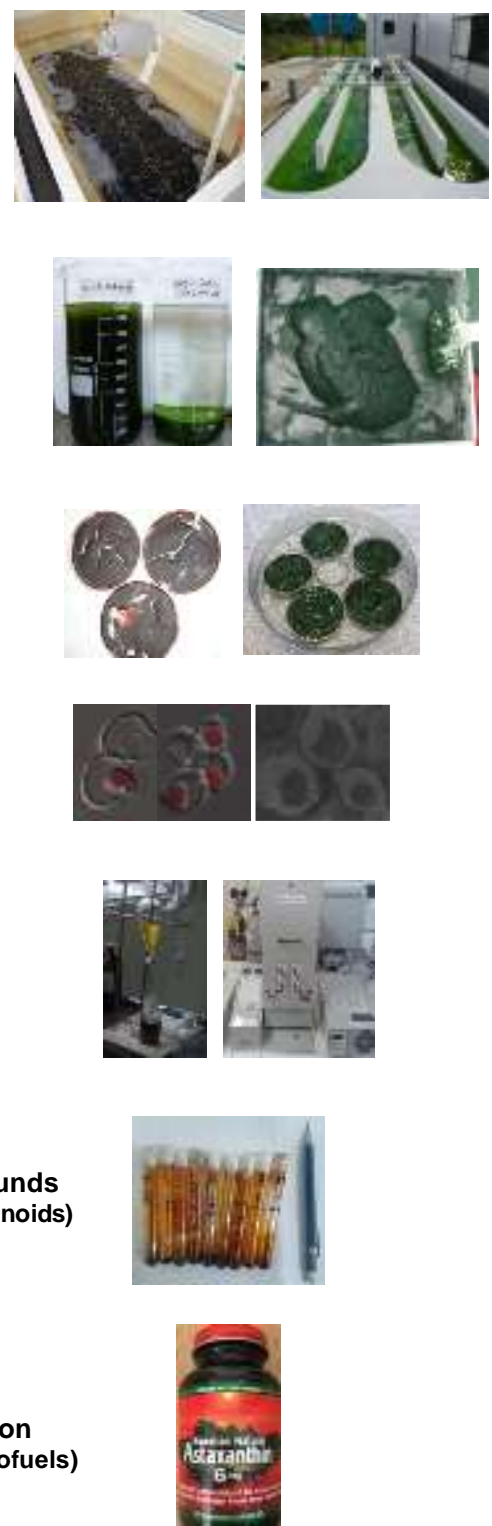

Figure 1. Microalgal biorefinery plant concept [21,22].

In the late 1990s, commercial production of the freshwater green alga Haematococcus pluvialis as a source of the carotenoid astaxanthin started in Hawaii, USA [23]. The culture system consists of a combination of closed photobioreactors and raceway ponds. Closed photobioreactors are mainly used for producing of high-value products such as pigments (phycocyanin and carotenoids), single cell protein and single cell oils composed by eicosapentaenoic, docosahexaenoic and arachidonic acids (EPA + DHA + AA) [24]. Photobioreactors have the distinct advantage of preventing water evaporation, reducing the risks of contaminants, limiting the $\mathrm{CO}_{2}$ losses and flexibility in technical design. The main disadvantages of closed 
systems are the high costs of construction and its technical operation such as pumping, cooling, cleaning and sterilization. Raceway ponds are the most usual setting for large-scale outdoor microalgae cultivation, which are considered low cost and easier to build and operate than closed photobioreactors [25].

Conventional microalgae production system consists of growth and cultivation of microalgae either in photobioreactors or raceway ponds, biomass recovery or harvesting, followed by further processing steps such as dewatering, drying, cell disruption, extraction and product purification (Figure 1).

\section{Investment on algal research in Brazil}

The exploitation of algal biomass for commercial purposes has prompted several research groups in different countries to seek the most appropriate algal production model associated to greater biomass productivity, environmental sustainability and economic viability [26-29]. Several nations, including Brazil, have invested in this development by funding researchers to advance our knowledge in algal biotechnology.

In 2008, the Ministry of Science, Technology and Innovation (Ministério da Ciência, Tecnologia e Inovação - MCTI) in partnership with the Secretary of Aquaculture and Fisheries (Secretaria de Aquicultura e Pesca) through the National Council of Scientific and Technological Development (Conselho Nacional de Desenvolvimento Científico e Tecnológico - CNPq), called for algal research proposals (MCTI/CNPq/MPA № 26/2008), funding $R \$ 4.5$ million (US\$ 1 million dollar) with the main purpose to support projects focused on producing biodiesel from microalgae. According to Franco et al. [30], 63 project proposals were submitted and the top eleven projects were selected. These funded projects addressed aspects of algal biology, development of algal cultivation techniques, designing photobioreactors and raceway ponds, modeling harvesting and dewatering process, maximizing biomass and oil productivities, characterizing chemical composition with different extractions systems, determining physiochemical properties of biodiesel, and evaluating techno-economic and life-cycle assessment of using algae as main source of biomass.

In 2013, CNPq (MCTI/CNPq № 56/2013) called again for proposals for R\&D on biofuels and bioproducts from microalgae with a gross funding of $\mathrm{R} \$ 11,230.000$ (US\$ $~ 2.5$ million dollars), divided in two categories: i) energy potential of microalgae for biodiesel production, and ii) biotechnological potential of microalgae within biorefineries. Seventeen top researchers with broad expertise from different Brazilian institutions were selected by $\mathrm{CNPq}$ to conduct further studies. The majority of the funding was awarded to researchers and institutions located in the south region of Brazil, as indicated in Figure 2. Except for the University of Passo Fundo (Universidade de Passo Fundo - UPF), all other institutions are public.

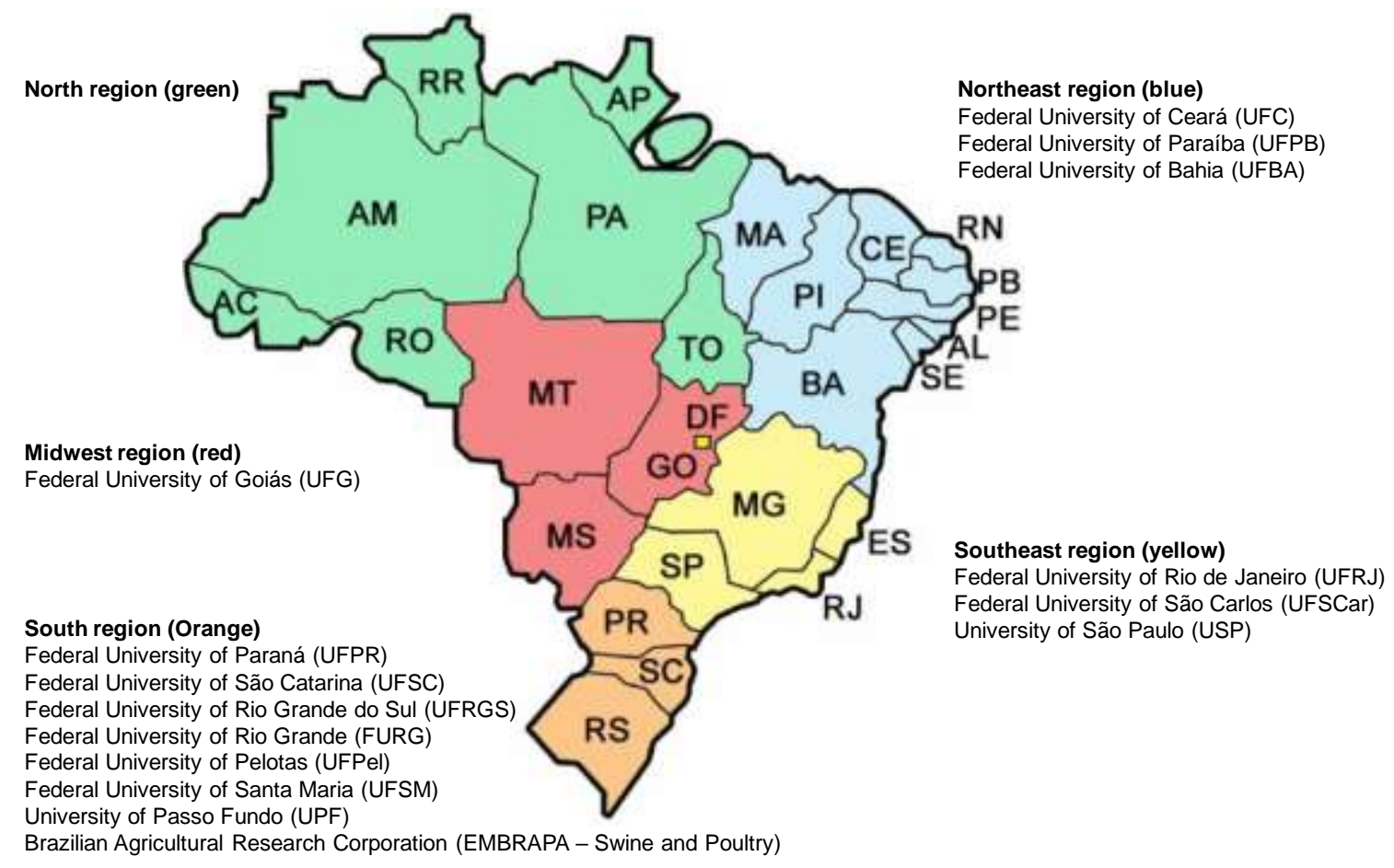

Figure 2. Institutions awarded financial support by the National Council of Scientific and Technological Development (CNPq) to advance projects in algal research. 
To track advances in algal biotechnology by Brazilian institutions, the Curriculum Lattes Platform (http://lattes.cnpq.br/), a virtual system created by CNPq, which integrates the curricular databases, research groups and institutions into a single information system, was used to screen the main articles on algal research published in the literature and results of this search are discussed below.

\section{Microalgae cultivation and production systems in Brazil}

In Brazil, microalgae cultivation has been performed either in photobioreactors or in open culture systems. An outstanding photobioreactor system with a volume capacity of $12,000 \mathrm{~L}$ was developed and patented by Federal University of Paraná (UFPR) researchers [31]. Another notable patented system, developed by Federal University of Santa Catarina (UFSC) researchers, includes a tubular photobioreactor combined with thin-layer cascades [32]. Both systems were designed for wastewater bioremediation through microalgal cultivation. Further examples about microalgal cultivation systems are shown in Table 1, together with the main microalgae species, culture medium and harvesting process. In addition, Jorquera et al. [26] analyzed and compared the energy life-cycle of oil-rich microalgae Nannochloropsis sp. for maximal biomass production cultivated in raceway open ponds $\left(0.35 \mathrm{~g} \mathrm{~L}^{-1}\right)$, in tubular $\left(1.02 \mathrm{~g} \mathrm{~L}^{-1}\right)$ and in flat-plate photobioreactor $\left(2.70 \mathrm{~g} \mathrm{~L}^{-1}\right)$ systems.

Several Brazilian researchers are studying the feasibility of using microalgae for wastewater treatment, which include, I) growth of Scenedesmus sp. using different concentrations of cattle manure effluent [33,34], ii) growth of Amphora sp. cultured in shrimp farm wastewater [35], iii) growth of Chlorella vulgaris, Spirulina platensis and Nannochloropsis gaditana in cultures mixed with different concentrations of desalination concentrate [36], iv) growth of Spirulina platensis in cultures with the addition of residues from the ultra and nanofiltration of whey protein [37], and $v$ ) growth of Arthrospira maxima OF15 using sugarcane vinasse for potential biological new peptides production [38]. These studies have been carried out from the analysis of laboratory-based and pilot-scale cultures, and most of the research are focused on evaluating the ability of microalgae to remove abundant organic and inorganic nutrients from wastewater associated with biomass production.

Harvesting is still a major hurdle in the microalgae production chain, representing for up to $30 \%$ of the total productions costs. It is believed that a two-stage process is required to concentrate microalgal biomass, such as flocculation followed by centrifugation. In reality, some studies as shown in Table 1, suggest prior flocculation of microalgae with cationic polymers, because these polymers neutralize the negative charge of microalgae before the centrifugation step $[31,39,40]$. Filtration techniques are another option that is applied in microalgae separation, especially for Spirulina species [41].

After dewatering, the microalgae biomass can be used directly as a source of animal feed or human food. In addition, many intracellular compounds can be extracted from microalgae and several studies on the extraction of high-value compounds by a wide range of analytical techniques have been conducted in Brazil (Table 2).

Table 1. Microalgae cultivation developed in Brazil using different systems from closed photobioreactors to open raceway ponds.

\begin{tabular}{llllll}
\hline $\begin{array}{l}\text { Cultivation } \\
\text { system }\end{array}$ & $\begin{array}{l}\text { Culture } \\
\text { volume }\end{array}$ & Microalgae & Culture medium & $\begin{array}{l}\text { Harvesting and } \\
\text { dewatering }\end{array}$ & Reference \\
\hline $\begin{array}{l}\text { Tubular } \\
\text { photobioreactor* }\end{array}$ & $10 \mathrm{~m}^{2} /$ & Scenedesmus sp. & $\begin{array}{l}\text { Biodigested swine } \\
\text { wastewater } \\
\text { diluted }(0.025 \mathrm{~L} / \mathrm{L})\end{array}$ & $\begin{array}{l}\text { Tanfloc }(210 \mathrm{mg} / \mathrm{L}) \text { at } \\
\mathrm{pH} 7.8\end{array}$ & {$[31]$} \\
& $12,000 \mathrm{~L}$ & & &
\end{tabular}

Tubular

photobioreactor

combined with

thin-layer

cascades**

Plexiglass bubble $30 \mathrm{~L}$
column

photobioreactors
$15.7 \mathrm{~L}$

Scenedesmus obliquus

Provasoli medium Centrifugation

$\begin{array}{ll}\text { Chlorella vulgaris } & \text { Wright's } \\ \text { and Nannochloropsis } & \begin{array}{l}\text { cryptophyte } \\ \text { oculata }\end{array} \\ \text { medium }\end{array}$ $\begin{array}{ll}\text { Chlorella vulgaris } & \text { Wright's } \\ \text { and Nannochloropsis } & \text { cryptophyte } \\ \text { oculata } & \text { medium }\end{array}$

$\begin{array}{ll}\text { Chlorella vulgaris } & \text { Wright's } \\ \text { and Nannochloropsis } & \text { cryptophyte } \\ \text { oculata } & \text { medium }\end{array}$
Twenty-five cationic polymers tested.

Tanfloc (5 mg/L) most

efficient and

economical option 
Cont.Table 1

\begin{tabular}{|c|c|c|c|c|c|}
\hline $\begin{array}{l}\text { Glass fiber } \\
\text { cylinder } \\
\text { photobioreactor, } \\
\text { open tank }\end{array}$ & $\begin{array}{l}180 \mathrm{~L} \text { and } \\
500 \mathrm{~L}\end{array}$ & $\begin{array}{l}\text { Nannochloropsis } \\
\text { oculata, } \\
\text { Phaeodactylum } \\
\text { tricornutum and } \\
\text { Porphyridium } \\
\text { cruentum }\end{array}$ & Conway media & $\begin{array}{l}\text { Continuous } \\
\text { centrifugation at } \\
12,000 \mathrm{rpm}\end{array}$ & [4] \\
\hline $\begin{array}{l}\text { Fiber cylinder } \\
\text { photobioreactor }\end{array}$ & $100 \mathrm{~L}$ & $\begin{array}{l}\text { Chlorella vulgaris, } \\
\text { Spirulina platensis, } \\
\text { Nannochloropsis } \\
\text { gaditana }\end{array}$ & $\begin{array}{l}\text { Bold Basal } \\
\text { medium, Paoletti } \\
\text { Synthetic } \\
\text { medium, F/2 } \\
\text { medium }\end{array}$ & $\begin{array}{l}\text { Continuous } \\
\text { centrifugation at } 4000 \\
\text { rpm for } \sim 1 \text { hour }\end{array}$ & [42] \\
\hline Raceway tanks & $250 \mathrm{~L}$ & $\begin{array}{l}\text { Arthrospira maxima } \\
\text { OF15 }\end{array}$ & $\begin{array}{l}\text { Sugarcane } \\
\text { vinasse }\end{array}$ & $\begin{array}{l}\text { Filtration with filter } \\
\text { press }\end{array}$ & [38] \\
\hline Raceway tanks & $240 \mathrm{~L}$ & Spirulina sp. LEB-18 & Zarrouk medium & $\begin{array}{l}\text { Centrifugation }(15,000 \\
g \times 15 \mathrm{~min})\end{array}$ & [41] \\
\hline $\begin{array}{l}\text { Outdoor raceway } \\
\text { tank }\end{array}$ & $2000 \mathrm{~L}$ & $\begin{array}{l}\text { Scenedesmus } \\
\text { obliquus }\end{array}$ & $\begin{array}{l}\text { Bold Basal } \\
\text { medium }\end{array}$ & $\begin{array}{l}\text { Two steps: } \\
\text { Flocculation (Flopam } \\
10 \mathrm{mg} / \mathrm{L}) \text { and } \\
\text { centrifugation }(12,000 \\
\text { rpm) }\end{array}$ & [40] \\
\hline $\begin{array}{l}\text { Open raceway } \\
\text { ponds }\end{array}$ & $4000 \mathrm{~L}$ & Chlorella vulgaris & $\begin{array}{l}\mathrm{BBM}+ \\
\text { Desalination } \\
\text { concentrate } \\
(25 \%)\end{array}$ & $\begin{array}{l}\text { Two steps: flocculation } \\
\left(1.0 \mathrm{~g} / \mathrm{L} \mathrm{CaCl}_{2} \text { and } \mathrm{pH}\right. \\
=10.5-12.0) \text { and } \\
\text { centrifugation ( } 3600 \\
\text { rpm continuously for } 3 \\
\text { h) }\end{array}$ & [43] \\
\hline Raceway ponds & $4000 \mathrm{~L}$ & Spirulina platensis & $\begin{array}{l}\mathrm{PSM}+ \\
\text { Desalination } \\
\text { concentrate } \\
(60 \%)\end{array}$ & $\begin{array}{l}\text { Filtration (sieve } 10 \mu \mathrm{m} \\
\text { diameter) }\end{array}$ & [44] \\
\hline $\begin{array}{l}\text { Open circular tank } \\
\text { system }\end{array}$ & $5000 \mathrm{~L}$ & $\begin{array}{l}\text { Scenedesmus } \\
\text { obliquus }\end{array}$ & $\begin{array}{l}\text { Bold Basal } \\
\text { medium }\end{array}$ & $\begin{array}{l}\text { Centrifuged (Sharples } \\
\text { S16 operating at } 6000 \\
\text { times } g \text { ) }\end{array}$ & [45] \\
\hline
\end{tabular}

* Patented process INPI Brazil (BR1020130263958 - Tubular photobioreactor for treatment of integrated liquid effluent and emissions)

** Patented process INPI Brazil (BR102016013102 - Device for effluent treatment and biomass production through aquatic organism cultivation)

\section{High-value products from microalgae in Brazil}

Recently Brazilian researchers have characterized intracellular compounds from microalgae (Table 2), and analyzed the proximate composition of moisture, ash, fiber, carbohydrate, protein, lipids and fatty acids in freshwater and marine microalgae species $[41,42,46]$.

Some microalgae, including the genus Chlorella are capable of accumulating intracellular starch in their cell walls, in addition to the presence of structural polysaccharides [47-49]. A study conducted by researchers from the Federal University of Rio de Janeiro (UFRJ) determined neutral sugars (glucose, galactose, rhamnose, arabinose and mannose), using an alternative assay based on one-step diluted sulfuric acid hydrolysis with reduced sample size, followed by high performance anion exchange chromatography (HPAEC) [50]. This one-step method was also successfully applied to another green microalga, i.e. Mychonastes homosphaera, indicating its applicability within the Chlorophyta phylum.

Chlorophyll and carotenoids are lipid-soluble pigments found in microalgae [51,52]. For instance, three carotenoid esters in Aphanotece microscopica and Phormidium autumnale were studied by the Federal University of Santa Maria (UFSM) researchers [53]. The authors emphasized that esterified carotenoids are more stable and possess higher antioxidant and bioavailability than non-esterified carotenoids, enabling to be incorporated in new food formulae, including functional foods. Feller et al. [4] from the UFSC evaluated the total carotenoids and antioxidant activity using DPPH free radical scavengers of three marine microalgal (Nannochloropsis oculata, Phaeodactylum tricornutum and Porphyridium cruentum) extracts after utilization of supercritical $\mathrm{CO}_{2}$ and subcritical $n$-butane apparatus extraction. Results indicated that Porphyridium cruentum extract by subcritical $n$-butane technique had potent scavenger activity mainly due to the 
antioxidant compounds, i.e., tocopherols, carotenoids, phycoerythrin and sulfated polysaccharides, found in this microalgae species.

Special studies have been carried out by researches from the Federal University of Rio Grande (FURG) and the University of Passo Fundo (UPF) on several compounds from Spirulina sp. LEB-18. For example, they investigated $i$ ) the techno-functional and physicochemical properties of protein concentrate as food enrichment [54]; ii) the purification of $C$-phycocyanin pigment by ultrafiltration for food, pharmaceutical and medical applications [55]; and iii) the extraction of polyhydroxyalkanoates (PHBs), to be used as polymer substitutes in water-based paint formulations. The blue colour of phycocyanin pigment makes it suitable as paint coloration while the phenolic compounds have antimicrobial properties due to their biocide effect [56].

Squalene and phytoesterols are a class of secondary metabolites that can be obtained from microalgae and have applications in medicine, food and the cosmetic industry $[8,9]$. Within this context, researchers from the UFSM characterized the compounds squalene and sterols (stigmasterol, cholesterol and $\beta$-sitosterol) in Phormidium autumnale, which was cultivated in a heterotrophic system after analysis of the biosynthesis pathways through lipidomics technique [8]. Squalene is traditionally extracted from the shark liver oil, but the biotechnological route of squalene production from microalgae is a way forward to avoid this resource that conflicts with marine wildlife preservation [57].

In summary, researchers from Brazilian institutions have advanced knowledge and expertise in extracting high-value products from a diverse microalgae species, using a wide range of analytical methodologies (Table 2). These above examples highlighted the exceptional qualities of microalgae to synthesize high-end products with potential market to be explored in Brazil.

Table 2. Chemical compounds and high-value products extracted from microalgae based on studies conducted by Brazilian institutions.

\begin{tabular}{ll}
\hline Metabolite analyzed & Main methodologies applied \\
\hline Moisture, mineral, dietary fiber, & Drying and heating samples, \\
protein, carbohydrate, lipid, fatty & enzymatic hydrolysis, Kjeldahl \\
acids & method, Soxhlet, gas \\
& chromatography
\end{tabular}

Elemental composition, protein, amino acids, sugars, lipids, fatty acids, carotenoids

Minerals determination

Lipids, fatty acids, total carotenoids

Lipids, fatty acids

Lipids, fatty acids

Carotenoids (violaxanthin, zeaxanthin, $\beta$-carotene) Protein, chlorophyll, lipids, amino acids, organic acids
Bligh and Dyer method, Kjeldahl method, thermogravimetric analysis, HPLC, GC, infrared spectrometry, total organic carbon analysis

Inductively coupled plasma optical emission spectrometry (ICP-OES) Supercritical $\mathrm{CO}_{2}$, subcritical $n$ butane, UV-Vis spectrophotometer

Soxhlet (hexane, ethanol, chloroform:methanol), compressed fluids (propane), supercritical $\left(\mathrm{CO}_{2}\right.$, ethanol, hexane)

Soxhlet (hexane), compressed fluids (propane), supercritical $\mathrm{CO}_{2}+$ $\mathrm{EtOH}$

High performance liquid chromatography (HPLC) Kjeldahl method, UV-Vis spectrophotometer, Soxhlet, HPLC, GC

\begin{tabular}{ll} 
Microalgae & Reference \\
\hline Chlorella vulgaris, Spirulina & {$[42]$} \\
platensis, Nannochloropsis & \\
gaditana, Nannochloropsis \\
oculata, Phaeodactylum \\
tricornutum, Porphyridium \\
cruentum
\end{tabular}

Chlorella sp.

Marine microalgae (36 algal species)

Nannochloropsis oculata,

Phaeodactylum

tricornutum, Porphyridium cruentum

Choricystis minor var. minor

Muriella decolor

Aphanothece microscopica, Phormidium autumnale Scenedesmus obliquus CPC05 
Cont. Table 2

\begin{tabular}{ll}
\hline Polyhydroxyalkanoates (PHBs) & Six different PHBs methods \\
& studied, property analysis (fourier \\
& transform infrared spectroscopy, \\
& molecular mass, X-ray diffraction, \\
& monomeric composition)
\end{tabular}

Protein (techno-functional and physicochemical properties)

Protein, lipids, peptides (nanoemulsions)

Proximate composition, nutritional content, physical properties (snack enriched with Spirulina)

Phenolic compounds, encapsulation (liposome), antifungal activity

Poly(3-hydroxybutyrate), Cphycocyanin, phenolic compounds (latex paint formulations)

Phycocyanin (food grade)

Squalene, sterols (cholesterol, $\beta$ sitosterol, stigmasterol)

Fatty acids, free amino acids, organic compounds (succinic, malic and citric acids)

Sugars and carbohydrates (arabinose, rhamnose, galactose, glucose, xylose, mannose, cellobiose)
Spirulina sp. LEB-18

[62]

Protein solubility, water absorption
capacity, foaming and emulsifying
properties, rheological behaviour
Enzymatic hydrolysis, degree
protein hydrolysis, nanoemulsions
preparation (ultra turrax), stability of
nanoemulsions, DPPH assay

Spirulina sp. LEB-18

[54]

Spirulina sp. LEB-18

nanoemulsions, DPPH assay

Extrusion, flavoring, in vitro protein digestibility, expansion index, bulk density, hardness, water absorption index and water solubility index, color analysis, scanning electron microscopy (SEM), microbiological, sensory and stability analyses

HPLC, multilamellar large vesicles liposome preparation, fourier transform infrared spectroscopy, nuclear magnetic resonance, differential scanning calorimetry

Paint characterization (density, solid content, pigment and hiding power, abrasion resistance and adhesion, drying time, resistance of paints to fungal growth, reflectance and emissivity)

Freeze-thaw extraction, microfiltration and ultrafiltration purification

Sterol extraction by direct saponification, gas chromatography identification

Bligh and Dyer method, gas chromatography identification

One-step dilute sulphuric acid hydrolysis followed by high performance anion exchange chromatography (HPAEC)
Spirulina sp. LEB-18

Spirulina sp. LEB-18

Spirulina sp. LEB-18

Arthrospira platensis

Phormidium autumnale

Chlorella vulgaris,

Scenedesmus obliquus,

Phormidium

Chlorella sorokiniana,

Mychonastes homosphaera

\section{Biofuels from microalgae in Brazil}

Due to the increasing interest in renewable energy, microalgae biomass is in the spotlight as a new source of biofuels such as biodiesel, bioethanol, biomethane and biohydrogen production (Table 3) $[48,66,67]$. Studies by researchers from the UFRJ, in partnership with Petrobras (Brazilian Petroleum Corporation), have particularly focused on this renewable route in the field of algal biofuels $[68,69]$. For example, Viêgas et al. [70] studied the synthesis of biodiesel and fuel properties from lipid-rich Chlorella species after in situ transesterification of biomass with later biodiesel deoxygenation to increase the oxidative stability of algal biodiesel.

Researchers from the Federal University of Bahia (UFBA) conducted a multivariate analysis of the potential of Botryococcus braunii for the biorefinery. It is one of the most scrutinized microalgal lipid producers and is rich in monounsaturated fatty acids. The data indicated that the biodiesel properties from this microalga are in accordance with international quality standards (EU, USA and Brazil) [27]. 
A partnership of researchers from the Federal University of Paraíba (UFPB) and the Federal University of Goiás (UFG) have studied the influence of chemical microelements (e.g., Zn, V, Tl, Ti, Sr, Sn, Pb, P, Ni, $\mathrm{Na}, \mathrm{Mo}, \mathrm{Mn}, \mathrm{Mg}, \mathrm{Li}, \mathrm{Fe}, \mathrm{Cu}, \mathrm{Cr}, \mathrm{Co}, \mathrm{Cd}, \mathrm{Ca}, \mathrm{Bi}, \mathrm{Be}, \mathrm{Ba}, \mathrm{B}, \mathrm{Al}$ ) in twenty-six marine microalgae species, for potential biodiesel production [58]. Such information is essential as these microelements can negatively affect biodiesel properties, such as storage durability, corrosion and damaging of fuel container, formation of gum and clogging in the engine, ash exhaust emissions, among others.

In addition to biodiesel production, the residual biomass also contains proteins, sugars and carbohydrates that can be used towards the production of bioethanol and biomethane [71-73]. In this context, the production of bioethanol by hydrolysis of the Spirulina sp. LEB-18 carbohydrate and corn starch, with subsequent alcoholic fermentation and distillation, was studied [71]. In a next step, the wastes of the enzymatic saccharification and alcoholic fermentation of Spirulina sp. LEB-18 residues were successfully utilized to produce biomethane through anaerobic digestion in a pilot-plant located at Embrapa Swine and Poultry (Concórdia, Santa Catarina, Brazil) [73]. This collaborative process represents a promising alternative to utilize the entire fraction of the microalgal biomass for generation of two combined biofuels products.

Biohydrogen production from microalgae has been demonstrated only at the laboratory scale, as highlighted by Federal University of Paraná (UFPR) researchers [74,75]. Their recent study evaluated biohydrogen production from Scenedesmus obliquus microalgae, cultivated in a $11 \mathrm{~L}$ airlift photobioreactor fed with hazardous diesel engine emissions [74]. Vargas et al. [75] proposed a mathematical model for hydrogen production in genetically modified Chlamydomonas reinhardtii, considered a model organism, and suggested that genetic improvements of the chloroplast $\mathrm{H}_{2}$ evolution activity would result in higher $\mathrm{H}_{2}$ production.

Table 3. Biofuels production from microalgae based on studies conducted by Brazilian researcher's institutions.

\begin{tabular}{|c|c|c|c|}
\hline $\begin{array}{l}\text { Type of } \\
\text { biofuel }\end{array}$ & Methodology & Microalgae & Reference \\
\hline Biodiesel & $\begin{array}{l}\text { Lipid and fatty acid quantification, biodiesel } \\
\text { calculated using empirical equations (multivariate } \\
\text { analysis) }\end{array}$ & $\begin{array}{l}\text { Botryococcus braunii (IBL- } \\
\text { C116) }\end{array}$ & [27] \\
\hline Biodiesel & $\begin{array}{l}\text { Lipid and fatty acid determination, biodiesel } \\
\text { predicated based on empirical equations }\end{array}$ & $\begin{array}{l}\text { Twelve freshwater algal } \\
\text { species }\end{array}$ & [28] \\
\hline Biodiesel & $\begin{array}{l}\text { Lipid and fatty acid determination, cell disruption by } \\
\text { non-thermal plasma, biodiesel estimations }\end{array}$ & $\begin{array}{l}\text { Nannochloropsis gaditana } \\
\text { (BMAK 130) }\end{array}$ & [76] \\
\hline Biodiesel & $\begin{array}{l}\text { Synthesis via in situ transesterification of algal oil } \\
\text { through catalytic deoxygenation }\end{array}$ & Chlorella sp. & [70] \\
\hline Bioethanol & $\begin{array}{l}\text { Simultaneous saccharification and fermentation of } \\
\text { algal biomass + corn starch }\end{array}$ & Spirulina sp. LEB-18 & [71] \\
\hline Biomethane & $\begin{array}{l}\text { Fermentation assays through anaerobic degradation } \\
\text { of algal biomass harvested from swine digestate } \\
\text { treatment }\end{array}$ & Scenedesmus spp. & [72] \\
\hline $\begin{array}{l}\text { Bioethanol } \\
\text { and } \\
\text { Biomethane }\end{array}$ & $\begin{array}{l}\text { Saccharification of algal biomass, alcoholic } \\
\text { fermentation, methane production through anaerobic } \\
\text { digestion }\end{array}$ & Spirulina platensis & [73] \\
\hline Biohydrogen & $\begin{array}{l}\text { Biophotolysis hydrogen generation analyzed through } \\
\text { numerical simulations }\end{array}$ & Scenedesmus obliquus & [74] \\
\hline Biohydrogen & $\begin{array}{l}\text { Modelling hydrogen production via genetic } \\
\text { modification }\end{array}$ & Chlamydomonas reinhardtii & [75] \\
\hline
\end{tabular}

\section{Studies on microalgae strain development in Brazil}

With growing interest in green microalgae, especially those microorganisms isolated from the natural environment, for biotechnological applications, the identification of green microalgae (phylum Chlorophyta) can be a difficult task and often requires careful microscopic examination of live cultured cells by a trained specialist. To advance the use of native strains from the local environment, fifty-one freshwater green 
microalgae isolated from natural freshwater bodies within the Amazon rainforest, the Cerrado savanna and the Pantanal flooded grasslands, were analyzed by DNA barcoding to identify corresponding species and deposited in the Collection of Microorganisms and Microalgae Applied to Agroenergy and Biorefineries at Embrapa (Brasília, Distrito Federal, Brazil) [77]. To establish a microalgae culture collection for the long-term, protocols for cryopreservation were optimized and validated for fifteen chlorophyte microalgae, based on intrinsic biological factors (i.e., cell morphology and phylogenetic origin) and cryoprotectant agent type [78].

Another method to identify microalgae utilizes the matrix-assisted laser desorption ionization time-offlight mass spectrometry (MALDI-TOF MS) technique. It was used by Federal University of São Carlos (UFSCar) researchers to differentiate freshwater coccoid green microalgae of the family Selenastraceae at the species and strain levels [79]. This robust technique discriminates green microalgae species through chemotaxonomy analysis after revealing a mass range from 0.4 to $2.0 \mathrm{kDa}$, making it a suitable and alternative method for application in algal taxonomic studies.

Some efforts have been channeled towards developing computational support for taxonomical classification of green microalgae species, especially in the Selenastraceae family [80]. In this context, Borges et al. [81] described a specialized methodology for segmenting 2D microscopy digital images of freshwater green microalgae. According to the authors, microalgae cell structures, such as mucilage and concavities are fundamental to recognize specific algae species, and these structures were segmented after incorporating specific smoothing and contrast enhancement steps based on descriptions of Gaussian distributions. Their proposed method for taxonomical classification achieved high segmentation accuracy when compared with ground-truth segmentations provided by an expert biologist.

The extensive biological diversity of algae can be leveraged to produce a wealthy of valuable bioproducts via genetic manipulation. Emerging technologies such as synthetic biology, molecular engineering, highthroughput phenomics and the application of internet of things (IOT) to algal technology can advance the understanding of algal biology at molecular level [82]. Implementation of high-tech engineering and molecular genetics approaches has effectively improved the productivity, cost-effectiveness and environmental impact of agricultural crops such as soy, corn, wheat and rice [83], which can be also applied to algal research [84]. Nannochloropsis species, for example, have been shown to outperform other industrial production candidates such as Chlorella or Tetraselmis species in terms of lipid productivity [85]. Researchers from the Synthetic Genomics Inc. (La Jolla, California, USA) have engineered a lipid-rich Nannochloropsis gaditana strain through CRISPR-Cas9 reverse-genetic modification that enabled to insert 18 transcriptional mutagenesis factors in different metabolic pathways, resulting in overproducing synthesis of triacylglycerols (TAG) [86]. In Australia, researchers investigated via genetic modification of marine diatom Phaeodactylum tricornutum, the extrachromosomal expression for the heterologous biosynthesis of monoterpenoid (geraniol), which is used as feedstock chemicals (fragrances, flavourings and cleaning agents) for a variety of polymers [87]. In Brazil, however, few researchers and institutions are working in this field and much effort and investments in research, training and education in algal molecular biology are needed to push forward the development of genetic manipulation of microalgae in Brazilian laboratories.

\section{Prospects of algal production in Brazil}

Brazil has approximately $12 \%$ of the world's freshwater supply, large tropical coastal area $(10,959 \mathrm{~km}$ in total) and receives an average insolation level of 8-22 MJ/m²/day. According to Brasil, Silva and Siqueira [66], there are over 40 laboratories and institutions in Brazil where algae cultures (microalgae, macroalgae and cyanobacteria) are kept, and about 3496 algae catalogued species, which makes it an excellent country to explore the biotechnological potential of both marine and freshwater microalgae species [88]. In addition, the northeast region of Brazil, known for its semiarid climate, ample solar irradiance, low seasonal variation, extensive arid lands and massive brackish groundwater has exceptional qualities to produce algae in large scale $[89,90]$. To date, however, few Brazilian companies are working in this field, for instance, two specific startups such as Séston Biotecnologia (Florianópolis, Santa Catarina) and Algae Biotecnologia (Holambra, São Paulo) have been cultivating microalgae in open raceways ponds, while the Brazilian company - Olson Nutrição, located in Camaquã (Rio Grande do Sul, Brazil) has been producing and manufacturing a native Arthrospira platensis species cultivated in greenhouse-covered raceway ponds with biomass production estimated to be around $400 \mathrm{Kg} /$ dry biomass in the year of 2020. In 2014, Bunge's global food oil sales started marketing AlgaWise ultra omega-9 fatty acid algae oil [91]. Manufacturing is taking place in a modest industrial plant with capacity to produce $100 \mathrm{Mt}$ of renewable oils per year. The industrial operation is located in São Paulo, Brazil that is adjacent to Bunge's Moema sugarcane mill [92]. The process utilizes sugarcane 
juice as carbon source for genetically modified microalgae cultivated in a closed heterotrophic system to produce oil for renewable chemicals (i.e., lubricants and cosmetics) [66].

An option to expand the cultivation of microalgae in Brazil is the integration of microalgae production to the sugarcane-ethanol industry [93,94]. Brazil is the leader producer of ethanol from sugarcane [95], and there are currently 400 sugarcane-ethanol production facilities in Brazil, mostly concentrated in Northeastern and Southeastern regions of the country [96]. Microalgae production and processing can be feasible coupled to sugarcane biorefineries as exemplified by Brasil et al. [66]. The same authors mentioned that renewable oils for industrial use and personal care can be produced from starch-rich microalgae grown on sucrose, vinasse and $\mathrm{CO}_{2}$, which are sub-products of ethanol industry [97]. Furthermore, these microalgae strains can be genetically modified to synthesize recombinant proteins such as cellulosic enzymes $[6,98]$.

The Petrobras company has been also making investments on microalgae production and processing in the petrochemical sector $[99,100]$. Petrobras currently explores oil in off shore and on shore platforms, giving rise to significant amounts of effluents, such as produced water and $\mathrm{CO}_{2}$. Microalgae can be cultivated using both of these effluents to generate oil-rich biomass [101]. Algae extracted oil or algae biocrude, which is generated by the hydrothermal treatment can be used as feedstock for the production of bio-based chemicals, biomaterials and biofuels [66]. In 2012, the company settled in the Northeastern costal region (Rio Grande do Norte state) of Brazil, due to its favorable hot climate and sunny days year-round, to start a pre-commercial operation of a native Nannochloropsis oculata strain cultivated in open raceway ponds [102].

\section{CONCLUSION}

This review elucidated the research conducted by Brazilian research institutions that have gathered a deep knowledge of microalgae biotechnology and have produced increasingly high quality research. It is noted that the researchers in Brazilian institutions are working in partnership and are bridging the gaps in microalgae science through interdisciplinary communications.

Several Brazilian institutions are developing projects on microalgae cultivation either in photobioreactors (tubular, cylinder, tanks) or raceway (open ponds) using an ample variety of microalgae species, including marine (e.g., Nannochloropsis oculata, Phaeodactylum tricornutum, Porphyridium cruentum), freshwater (e.g., Chlorella sp., Scenedemus sp., Chlamydomonas reinhardtii, Botryococcus braunii) and cyanobacteria (e.g., Spirulina platensis, Phormidium autumnale, Aphanothece microscopica). In addition, researches are also exploring and evaluating the bioremediation of wastewater through microalgae cultivation. Some efforts have been done on determination of chemical composition and extraction of high-value products (e.g., phenolic compounds, polyhydroxyalkanoates, phycocyanin, carotenoids, $\omega-3$ fatty acids, amino acids, sterols, squalene, peptides) from these microalgae, using a wide range of analytical techniques. Other researchers are interested in investigating the biofuel production from microalgae such as biodiesel, bioethanol, biomethane and biohydrogen, and few works are focused on strain development and genetic engineering of microalgae.

With the recently growing number of research groups focusing on different trends within algal biotechnology across Brazil, a next step would be creating a forum between academic and industrial sectors and establish a platform for scientific discussion and network communication, encouraging new collaborations across all disciplines of algal research. Such as forum may simulate the connection between fundamental algal research and industrial applications and facilitate the transfer of academic results to commercial engagement.

Acknowledgments: the author would like to thank the Conselho Nacional de Desenvolvimento Científico e Tecnológico (CNPq) for funding Prof. Dr. Ernani S. Sant'Anna to the project 'Microalgae: an alternative source for bioproducts and biodiesel production in the semiarid region of Brazil' under contract number 574.716/2008-4.

\section{REFERENCES}

1. Matos ÂP. Microalgae as a Potential Source of Proteins. In: Galanakis CM, editor. Proteins: Sustainable Source, Processing and Applications: Academic Press; 2019. p. 63-96.

2. Freitas BCBd, Cassuriaga APA, Morais MGd, Atala DIP, Costa JAV. Pentoses used in cultures of Synechococcus nidulans and Spirulina paracas: evaluation of effects in growth and in content of proteins and carbohydrates. Braz Arch Biol Technol. 2019;62.

3. Matos ÂP. Essential fatty acids from microalgae. Inform. 2016;27(10):23. 
4. Feller R, Matos ÂP, Mazzutti S, Moecke EHS, Tres MV, Derner RB, et al. Polyunsaturated $\omega-3$ and $\omega-6$ fatty acids, total carotenoids and antioxidant activity of three marine microalgae extracts obtained by supercritical $\mathrm{CO}_{2}$ and subcritical $n$-butane. J Supercrit Fluid. 2018;133:437-43.

5. Wang Z, Ganewatta MS, Tang C. Sustainable polymers from biomass: Bridging chemistry with materials and processing. Prog Polym Sci. 2020;101:101197.

6. Brasil BdSAF, de Siqueira FG, Salum TFC, Zanette CM, Spier MR. Microalgae and cyanobacteria as enzyme biofactories. Algal Res. 2017;25:76-89.

7. Grecia M, Luciana V, Vanete S, Júlio C, Carlos S. The antihypertensive, antimicrobial and anticancer peptides from Arthrospira with therapeutic potential: A minireview. Curr Mol Med. 2020;20:1.

8. Fagundes MB, Falk RB, Facchi MMX, Vendruscolo RG, Maroneze MM, Zepka LQ, et al. Insights in cyanobacteria lipidomics: A sterols characterization from Phormidium autumnale biomass in heterotrophic cultivation. Food Res Int. 2019;119:777-84.

9. Matos ÂP. The impact of microalgae in food science and technology. J Am Oil Chem Soc. 2017;94(11):1333-50.

10. Coêlho DdF, Tundisi LL, Cerqueira KS, Rodrigues JRdS, Mazzola PG, Tambourgi EB, et al. Microalgae: cultivation aspects and bioactive compounds. Braz Arch Biol Technol. 2019;62.

11. de Siqueira Castro J, Calijuri ML, Ferreira J, Assemany PP, Ribeiro VJ. Microalgae based biofertilizer: A life cycle approach. Sci Total Environ. 2020:138138.

12. Silva CEdF, Bertucco A. Bioethanol from Microalgal Biomass: A Promising Approach in Biorefinery. Braz Arch Biol Technol. 2019;62.

13. Feller R, Matos A, Moecke E, Carvalho Jr R, Lopes R, Camargo C, et al. Comparative study of biochemical composition of five microalgae for biodiesel/bioproducts application. Blucher Chem Eng Proceed. 2015;1(2):1499-506.

14. Ishika T, Moheimani NR, Bahri PA. Sustainable saline microalgae co-cultivation for biofuel production: a critical review. Renew Sust Energ Rev. 2017;78:356-68.

15. Borowitzka MA. Commercial production of microalgae: ponds, tanks, and fermenters. Progress in industrial microbiology. Volume 35: Elsevier; 1999. p 313-21.

16. Vonshak A. Spirulina platensis arthrospira: physiology, cell-biology and biotechnology: CRC Press; 2014.

17. Oren A. A hundred years of Dunaliella research: 1905-2005. Sal Syst. 2005;1(1):2.

18. Batac CPC, Gathercole NSJ, Maravilla AKF, Beltran AB. Evaluation of Spirulina platensis in bicarbonate-based integrated carbon capture and algae production system utilizing different culture media. ASEAN J Chem Eng. 2020;20(1):77-87.

19. Ishika T, Moheimani NR, Laird DW, Bahri PA. Stepwise culture approach optimizes the biomass productivity of microalgae cultivated using an incremental salinity increase strategy. Biomass Bioenerg. 2019;127:105274.

20. Vadiveloo A, Matos AP, Chaudry S, Bahri PA, Moheimani NR. Effect of $\mathrm{CO}_{2}$ addition on treating anaerobically digested abattoir effluent (ADAE) using Chlorella sp. (Trebouxiophyceae). $\mathrm{J} \mathrm{CO}_{2}$ Util. 2020;38:273-81.

21. Matos ÂP. Cultivo, caracterização e técnicas de processamento de algas. Universidade Federal de Santa Catarina, Brazil (Doutorado em Ciência dos Alimentos), 2017. 214p.

22. Feller R. Microalgae biomass as a source of natural compounds: chemical characterization and new approaches for lipid extraction and culture harvesting. Universidade Federal de Santa Catarina, Brazil (Doutorado em Engenhria Química), 2017. 146p.

23. Lorenz RT, Cysewski GR. Commercial potential for Haematococcus microalgae as a natural source of astaxanthin. Trends Biotechnol. 2000;18(4):160-7.

24. Ruiz J, Olivieri G, de Vree J, Bosma R, Willems P, Reith JH, et al. Towards industrial products from microalgae. Energ Environ Sci. 2016;9(10):3036-43.

25. Kumar K, Mishra SK, Shrivastav A, Park MS, Yang J-W. Recent trends in the mass cultivation of algae in raceway ponds. Renew Sust Energ Rev. 2015;51:875-85.

26. Jorquera O, Kiperstok A, Sales EA, Embiruçu M, Ghirardi ML. Comparative energy life-cycle analyses of microalgal biomass production in open ponds and photobioreactors. Bioresour Technol. 2010;101(4):1406-13.

27. Cabanelas ITD, Marques SSI, de Souza CO, Druzian JI, Nascimento IA. Botryococcus, what to do with it? Effect of nutrient concentration on biorefinery potential. Algal Res. 2015;11:43-9.

28. Calixto CD, da Silva Santana JK, Tibúrcio VP, de Pontes LdFBL, da Costa Sassi CF, da Conceição $\mathrm{MM}$, et al. Productivity and fuel quality parameters of lipids obtained from 12 species of microalgae from the northeastern region of Brazil. Renew Energ. 2018;115:1144-52. 
29. de Queiroz Fernandes Araújo O, Luiz de Medeiros J, Yokoyama L, do Rosário Vaz Morgado C. Metrics for sustainability analysis of post-combustion abatement of $\mathrm{CO}_{2}$ emissions: Microalgae mediated routes and CCS (carbon capture and storage). Energ. 2015;92:556-68.

30. Franco ALC, Lôbo IP, Cruz RSd, Teixeira CMLL, Almeida Neto JAd, Menezes RS. Biodiesel de microalgas: avanços e desafios. Quím Nova. 2013;36:437-48.

31. Selesu NFH, V. de Oliveira T, Corrêa DO, Miyawaki B, Mariano AB, Vargas JVC, et al. Maximum microalgae biomass harvesting via flocculation in large scale photobioreactor cultivation. Can J Chem Eng. 2016;94(2):304-9.

32. Tramontin DP, Gressler PD, Rörig LR, Derner RB, Pereira-Filho J, Radetski CM, et al. Growth modeling of the green microalga Scenedesmus obliquus in a hybrid photobioreactor as a practical tool to understand both physical and biochemical phenomena in play during algae cultivation. Biotechnol Bioeng. 2018;115(4):965-77.

33. Scherer MD, de Oliveira AC, Filho FJCM, Ugaya CML, Mariano AB, Vargas JVC. Environmental study of producing microalgal biomass and bioremediation of cattle manure effluents by microalgae cultivation. Clean Technol Environ. 2017;19(6):1745-59.

34. Scherer MD, Filho FJCM, Oliveira AC, Selesu NFH, Ugaya CML, Mariano AB, et al. Environmental evaluation of flocculation efficiency in the separation of the microalgal biomass of Scenedesmus sp. cultivated in full-scale photobioreactors. J Environ Sci Health, Part A. 2018;53(10):938-45.

35. Sassi PGP, Calixto CD, Tibúrcio VP, da Silva Nonato N, Abrahão R, Hégaret $\mathrm{H}$, et al. Effectiveness of nutrient remotion and cell physiology of Amphora sp. cultured in shrimp farm effluents. Environ Sci Pollut Res. 2018;25(18):17920-6.

36. Matos ÂP, Moecke EHS, Sant'Anna ES. The use of desalination concentrate as a potential substrate for microalgae cultivation in Brazil. Algal Res. 2017;24:505-8.

37. Vieira Salla AC, Margarites AC, Seibel FI, Holz LC, Brião VB, Bertolin TE, et al. Increase in the carbohydrate content of the microalgae Spirulina in culture by nutrient starvation and the addition of residues of whey protein concentrate. Bioresour Technol. 2016;209:133-41.

38. Montalvo GEB, Thomaz-Soccol V, Vandenberghe LPS, Carvalho JC, Faulds CB, Bertrand E, et al. Arthrospira maxima OF15 biomass cultivation at laboratory and pilot scale from sugarcane vinasse for potential biological new peptides production. Bioresour Technol. 2019;273:103-13.

39. Roselet F, Vandamme D, Roselet M, Muylaert K, Abreu PC. Screening of commercial natural and synthetic cationic polymers for flocculation of freshwater and marine microalgae and effects of molecular weight and charge density. Algal Res. 2015;10:183-8.

40. Oliveira CYBd, Viegas TL, Lopes RG, Cella H, Menezes RS, Soares AT, et al. A comparison of harvesting and drying methodologies on fatty acids composition of the green microalga Scenedesmus obliquus. Biomass Bioenerg. 2020;132:105437.

41. de Jesus CS, da Silva Uebel L, Costa SS, Miranda AL, de Morais EG, de Morais MG, et al. Outdoor pilot-scale cultivation of Spirulina sp. LEB-18 in different geographic locations for evaluating its growth and chemical composition. Bioresour Technol. 2018;256:86-94.

42. Matos ÂP, Feller R, Moecke EHS, de Oliveira JV, Junior AF, Derner RB, et al. Chemical characterization of six microalgae with potential utility for food application. J Am Oil Chem Soc. 2016;93(7):963-72.

43. Matos ÂP, Ferreira WB, Morioka LRI, Moecke EHS, França KB, Sant Anna ES. Cultivation of Chlorella vulgaris in medium supplemented with desalination concnetrate grown in a pilot-scale open raceway. Braz J Cheml Eng. 2018;35:1183-92.

44. Matos ÂP, da Silva T, Sant'Anna ES. The feasibility of using inland desalination concentrate (DC) as an alternative substrate for Spirulina platensis mass cultivation. Waste Biomass Valori. 2020.

45. Simioni T, Quadri MB, Derner RB. Drying of Scenedesmus obliquus: Experimental and modeling study. Algal Res. 2019;39:101428.

46. Viegas CV, Hachemi I, Mäki-Arvela P, Smeds A, Aho A, Freitas SP, et al. Algal products beyond lipids: Comprehensive characterization of different products in direct saponification of green alga Chlorella sp. Algal Res. 2015;11:156-64.

47. dos Santos RR, Moreira DM, Kunigami CN, Aranda DAG, Teixeira CMLL. Comparison between several methods of total lipid extraction from Chlorella vulgaris biomass. Ultrason Sonochem. 2015;22:95-9.

48. Rodrigues MA, Teixeira RSS, Ferreira-Leitão VS, da Silva Bon EP. Untreated Chlorella homosphaera biomass allows for high rates of cell wall glucan enzymatic hydrolysis when using exoglucanase-free cellulases. Biotechnol Biofuel. 2015;8(1):25. 
49. de Souza MF, Rodrigues MA, Bon EPdS, Freitas SP. Interference of starch accumulation in microalgal cell growth measurement. J Appl Phycol. 2019;31(1):249-54.

50. Souza MFd, Pereira DS, Freitas SP, Bon EPdS, Rodrigues MA. Neutral sugars determination in Chlorella: Use of a one-step dilute sulfuric acid hydrolysis with reduced sample size followed by HPAEC analysis. Algal Res. 2017;24:130-7.

51. do Nascimento TC, Cazarin CBB, Roberto Maróstica M, Risso ÉM, Amaya-Farfan J, Grimaldi R, et al. Microalgae biomass intake positively modulates serum lipid profile and antioxidant status. J Funct Foods. 2019;58:11-20.

52. Lucas BF, Morais MGd, Santos TD, Costa JAV. Spirulina for snack enrichment: Nutritional, physical and sensory evaluations. LWT. 2018;90:270-6.

53. Manzoni Maroneze M, Jacob-Lopes E, Queiroz Zepka L, Roca M, Pérez-Gálvez A. Esterified carotenoids as new food components in cyanobacteria. Food Chem. 2019;287:295-302.

54. Lupatini Menegotto AL, Souza LESd, Colla LM, Costa JAV, Sehn E, Bittencourt PRS, et al. Investigation of techno-functional and physicochemical properties of Spirulina platensis protein concentrate for food enrichment. LWT. 2019;114:108267.

55. Brião VB, Sbeghen AL, Colla LM, Castoldi V, Seguenka B, Schimidt GdO, et al. Is downstream ultrafiltration enough for production of food-grade phycocyanin from Arthrospira platensis? J Appl Phycol. 2020.

56. Cruz CG, da Silveira JT, Ferrari FM, Costa JAV, da Rosa APC. The use of poly(3-hydroxybutyrate), C-phycocyanin, and phenolic compounds extracted from Spirulina sp. LEB 18 in latex paint formulations. Prog Org Coat. 2019;135:100-4.

57. Fagundes MB, Vendruscolo RG, Maroneze MM, Barin JS, de Menezes CR, Zepka LQ, et al. Towards a sustainable route for the production of squalene using cyanobacteria. Waste Biomass Valori. 2019;10(5):1295-302.

58. Silva BF, Wendt EV, Castro JC, Oliveira AEd, Carrim AJI, Vieira JDG, et al. Analysis of some chemical elements in marine microalgae for biodiesel production and other uses. Algal Res. 2015;9:312-21.

59. da Cruz Lima AA, Szczerbowski D, Zandoná Filho A, Derner RB, Corazza ML, Ramos LP. Choricystis minor var. minor lipids: Extraction using conventional and pressurized solvents and assessment of their potential to produce fatty acid methyl esters. Algal Res. 2018;33:28-35.

60. da Silva Nonato N, Nottar Escobar EL, Kochepka DM, Bianchini Derner R, Montes D'Oca MG, Corazza ML, et al. Extraction of Muriella decolor lipids using conventional and pressurized solvents and characterization of their fatty acid profile for biodiesel applications. J Supercrit Fluid. 2020;158:104750.

61. Vendruscolo RG, Fagundes MB, Maroneze MM, do Nascimento TC, de Menezes CR, Barin JS, et al. Scenedesmus obliquus metabolomics: effect of photoperiods and cell growth phases. Bioproc Biosyst Eng. 2019;42(5):727-39.

62. Costa SS, Miranda AL, Assis DdJ, Souza CO, de Morais MG, Costa JAV, et al. Efficacy of Spirulina sp. polyhydroxyalkanoates extraction methods and influence on polymer properties and composition. Algal Res. 2018;33:231-8.

63. Costa AM, Bueno KTL, Rosa APCd, Costa JAV. The antioxidant activity of nanoemulsions based on lipids and peptides from Spirulina sp. LEB18. LWT. 2019;99:173-8.

64. Pagnussatt FA, de Lima VR, Dora CL, Costa JAV, Putaux J-L, Badiale-Furlong E. Assessment of the encapsulation effect of phenolic compounds from Spirulina sp. LEB-18 on their antifusarium activities. Food Chem. 2016;211:616-23.

65. Vendruscolo RG, Facchi MMX, Maroneze MM, Fagundes MB, Cichoski AJ, Zepka LQ, et al. Polar and non-polar intracellular compounds from microalgae: Methods of simultaneous extraction, gas chromatography determination and comparative analysis. Food Res Int. 2018;109:204-12.

66. Brasil B, Silva F, Siqueira F. Microalgae biorefineries: the Brazilian scenario in perspective. New Biotechnol. 2017;39:90-8.

67. Carioca JOB, Hiluy Filho JJ, Leal MRLV, Macambira FS. The hard choice for alternative biofuels to diesel in Brazil. Biotechnol Adv. 2009;27(6):1043-50.

68. de Souza LM, Mendes PAS, Aranda DAG. Assessing the current scenario of the Brazilian biojet market. Renew Sust Energ Rev. 2018;98:426-38.

69. de Souza LM, Mendes PAS, Aranda DAG. Oleaginous feedstocks for hydro-processed esters and fatty acids (HEFA) biojet production in southeastern Brazil: A multi-criteria decision analysis. Renew Energ. 2020;149:1339-51. 
70. Viêgas CV, Hachemi I, Freitas SP, Mäki-Arvela P, Aho A, Hemming J, et al. A route to produce renewable diesel from algae: Synthesis and characterization of biodiesel via in situ transesterification of Chlorella alga and its catalytic deoxygenation to renewable diesel. Fuel. 2015;155:144-54.

71. Luiza Astolfi A, Rempel A, Cavanhi VAF, Alves M, Deamici KM, Colla LM, et al. Simultaneous saccharification and fermentation of Spirulina sp. and corn starch for the production of bioethanol and obtaining biopeptides with high antioxidant activity. Bioresour Technol. 2020;301:122698.

72. Perazzoli S, Bruchez BM, Michelon W, Steinmetz RLR, Mezzari MP, Nunes EO, et al. Optimizing biomethane production from anaerobic degradation of Scenedesmus spp. biomass harvested from algae-based swine digestate treatment. Int Biodeter Biodegr. 2016;109:23-8.

73. Rempel A, de Souza Sossella F, Margarites AC, Astolfi AL, Steinmetz RLR, Kunz A, et al. Bioethanol from Spirulina platensis biomass and the use of residuals to produce biomethane: An energy efficient approach. Bioresour Technol. 2019;288:121588.

74. Corrêa DO, Santos B, Dias FG, Vargas JVC, Mariano AB, Balmant W, et al. Enhanced biohydrogen production from microalgae by diesel engine hazardous emissions fixation. Int $\mathrm{J}$ Hydro Energ. 2017;42(33):21463-75.

75. Vargas JVC, Kava V, Balmant W, Mariano AB, Ordonez JC. Modeling microalgae derived hydrogen production enhancement via genetic modification. Int J Hydro Energ. 2016;41(19):8101-10.

76. Matos ÂP, Teixeira MS, Corrêa FMPS, Machado MM, Werner RIS, Aguiar AC, et al. Disruption of Nannochloropsis gaditana (Eustigmatophyceae) rigid cell wall by non-thermal plasma prior to lipid extraction and its effect on fatty acid composition. Braz J Chem Eng. 2019;36:1419-28.

77. Hadi SI, Santana H, Brunale PP, Gomes TG, Oliveira MD, Matthiensen A, et al. DNA barcoding green microalgae isolated from neotropical inland waters. PloS one. 2016;11(2).

78. Fernandes MS, Calsing LCG, Nascimento RC, Santana H, Morais PB, de Capdeville G, et al. Customized cryopreservation protocols for chlorophytes based on cell morphology. Algal Res. 2019;38:101402.

79. Mello RV, Meccheri FS, Bagatini IL, Rodrigues-Filho E, Vieira AAH. MALDI-TOF MS based discrimination of coccoid green microalgae (Selenastraceae, Chlorophyta). Algal Res. 2017;28:15160.

80. Borges VRP, Hamann B, Silva TG, Vieira AA, Oliveira MCF. A highly accurate level set approach for segmenting green microalgae images. 2015. IEEE. p 87-94.

81. Borges VRP, Oliveira MCFd, Silva TG, Vieira AAH, Hamann B. Region growing for segmenting green microalgae images. IEEE/ACM Trans Comput Biol Bioinform. 2018;15(1):257-70.

82. Fabris M, Abbriano RM, Pernice M, Sutherland DL, Commault AS, Hall CC, et al. Emerging technologies in algal biotechnology: Toward the establishment of a sustainable, algae-based bioeconomy. Front Plant Sci. 2020;11.

83. Mir RR, Reynolds M, Pinto F, Khan MA, Bhat MA. High-throughput phenotyping for crop improvement in the genomics era. Plant Sci. 2019;282:60-72.

84. Vermuë M, Eppink M, Wijffels R, Van Den Berg C. Multi-product microalgae biorefineries: from concept towards reality. Trends Biotechnol. 2018;36(2):216-27.

85. Kilian O, Benemann CS, Niyogi KK, Vick B. High-efficiency homologous recombination in the oilproducing alga Nannochloropsis sp. P Natl Acad Sci. 2011;108(52):21265-9.

86. Ajjawi I, Verruto J, Aqui M, Soriaga LB, Coppersmith J, Kwok K, et al. Lipid production in Nannochloropsis gaditana is doubled by decreasing expression of a single transcriptional regulator. Nature Biotechnol. 2017;35(7):647.

87. Fabris M, George J, Kuzhiumparambil U, Lawson CA, Jaramillo-Madrid AC, Abbriano RM, et al. Extrachromosomal genetic engineering of the marine diatom Phaeodactylum tricornutum enables the heterologous production of monoterpenoids. ACS Synth Biol. 2020;9(3):598-612.

88. Menezes M, Bicudo CE, Moura CW, Alves AM, Santos AA, Pedrini AdG, et al. Update of the Brazilian floristic list of algae and cyanobacteria. Rodriguésia. 2015;66(4):1047-62.

89. Sánchez A, Nogueira I, Kalid R. Uses of the reject brine from inland desalination for fish farming, Spirulina cultivation, and irrigation of forage shrub and crops. Desalination. 2015;364:96-107.

90. Sánchez AS, Matos ÂP. Desalination concentrate management and valorization methods. Sustainable Desalination Handbook: Elsevier; 2018. p 351-99.

91. Kligerman DC, Bouwer EJ. Prospects for biodiesel production from algae-based wastewater treatment in Brazil: A review. Renew Sust Energ Rev. 2015;52:1834-46.

92. El-Assad AB, Van-Dal ES, Lopes MSG, de Andrade Coutinho PL, do Carmo RW, Jaconis SB. Technologies, products and economic viability of a sugarcane biorefinery in Brazil. Chem Fuel BioBased Build Block. 2016:569-602. 
93. Klein BC, Bonomi A, Maciel Filho R. Integration of microalgae production with industrial biofuel facilities: A critical review. Renew Sust Energ Rev. 2018;82:1376-92.

94. Souza SP, Gopal AR, Seabra JE. Life cycle assessment of biofuels from an integrated Brazilian algaesugarcane biorefinery. Energ. 2015;81:373-81.

95. Goldemberg J. Ethanol for a sustainable energy future. Science. 2007;315(5813):808-10.

96. Damaso MCT, Machado CMM, de Sousa Rodrigues D, Belem SG, Salum TFC. Bioprocesses for biofuels: an overview of the Brazilian case. Chem Biol Technol Agricult. 2014;1(1):1-8.

97. Santana H, Cereijo CR, Teles VC, Nascimento RC, Fernandes MS, Brunale P, et al. Microalgae cultivation in sugarcane vinasse: selection, growth and biochemical characterization. Bioresour Technol. 2017;228:133-40.

98. Rasala BA, Mayfield SP. Photosynthetic biomanufacturing in green algae; production of recombinant proteins for industrial, nutritional, and medical uses. Photosynth Res. 2015;123(3):227-39.

99. Andrade DS, Telles TS, Castro GHL. The Brazilian microalgae production chain and alternatives for its consolidation. J Clean Prod. 2020;250:119526.

100. Sampaio RM, Bonacelli MBM. Biodiesel in Brazil: Agricultural R\&D at Petrobras Biocombustível. J Technol Manag Innovat. 2018;13(1):66-74.

101. dos Santos MGB, Duarte RL, Maciel AM, Abreu M, Reis A, de Mendonça HV. Microalgae biomass production for biofuels in brazilian scenario: a critical review. BioEnerg Res. 2020:1-20.

102. Arriada AdA, Abreu P. Nannochloropsis oculata growth in produced water: an alternative for massive microalgae biomass production. Braz J Petrol Gas. 2014;8(3).

(C) 2021 by the authors. Submitted for possible open access publication under the terms and conditions of the Creative Commons Attribution (CC BY NC) license (https://creativecommons.org/licenses/by-nc/4.0/). 